\title{
Accumulation Characteristics and Risk Assessment of Potentially Toxic Elements for Major Crops and Farmland Around A High-arsenic Coal Mine in Xingren, Guizhou, Southwest China
}

\author{
F.X. Qin*(**)†, Y. Yi**, J.Y. Gong**, Y.B. Zhang*, K. Hong* and Y.K. Li** \\ * School of Life sciences, Guizhou Normal University, Guiyang 550001, P.R. China \\ **Key Laboratory of State Forestry Administration on Biodiversity Conservation in Karst Mountainous Areas of South- \\ western China, Guizhou Normal University, Guiyang 550001, P.R. China \\ $\dagger$ Corresponding author: Fanxin Qin; fanxq0822@163.com
}

Nat. Env. \& Poll. Tech. Website: www.neptjournal.com

Received: 22-08-2019

Revised: $02-10-2019$

Accepted: 07-11-2019

Key Words:

Toxic elements

Target hazard quotient

Health Risk

Coal Mine

Crops

\begin{abstract}
This study assessed the contamination by toxic elements (TEs), including lead (Pb), cadmium (Cd), chromium $(\mathrm{Cr})$, zinc $(\mathrm{Zn})$, copper $(\mathrm{Cu})$ and arsenic $(\mathrm{As})$, and their accumulation characteristics in soilcrop systems in Xingren, Guizhou, southwest China, by using the target hazard quotient (THQ) to evaluate the possible health risk in the target area. The mean value of the geo-accumulation index $\left(\mathrm{I}_{\text {geo }} ; 1.95,1.89\right.$ and 1.96 for rice, maize and Coix lacryma-jobi L., respectively) shows As in partial contamination level. The potential ecological risk index (RI) values show that $90 \%$ of samples exceed in considerable ecology risk level $(120<$ RI 240$)$. The concentration of investigated TEs (except Zn) in the edible part of the three crops tended to be lower than in other tissues: root $>$ stalk $>$ leaf $>$ husk >edible part. Maize showed a major restriction in TE intake compared to rice and Coix lacryma-jobi L. The THQ of As was from 0 to 6.33 in all the plant samples, which indicates that the THQ exceeded the safe limit $(T H Q=1)$ in some samples. The total THQs (TTHQ) had a similar trend as RI, further indicating the potential health risk of the elements in combination. These data indicate that local people experience significant health risks if they ingest crops from the investigated area.
\end{abstract}

\section{INTRODUCTION}

Toxic elements (TEs) are ubiquitously distributed in the pedosphere and the geosphere. Soil TE contamination is an environmental issue in China and worldwide (Sun et al. 2010) because of its adverse impacts, such as contamination of water and soil, phytotoxicity, biotoxicity, accumulative behaviour and potential human health risk (Yu et al. 2008). Eating plants from the contaminated area or inhalation of polluted particles are the principal factors contributing to TE exposure for the human population (Loutfy et al. 2006).

For instance, it has been recognised that the food chain can serve as an important pathway of TE exposure for humans and animals (Dudka \& Miller 1999). TEs are likely to transfer and accumulate through the soil-crop system and thus may affect the quality of agricultural products and cause health risks to humans (Mico et al. 2006). Total TE content in soils is directly related to the background level, but anthropogenic activities seem to have the far-reaching impact (Singani \& Ahmadi 2012). Anthropogenic activities, including mining, sewage irrigation and vehicular exhaust, are the major sources of TE pollution of farmland ( $\mathrm{Li}$ et al.
2014). TE contamination in the vicinity of mining areas is mainly from smelting and refining, wastewater discharge and tailings disposal. Levels of TE pollution of air, water, sediments, soil and crops in the mine-affected areas are reported to be greatly higher than areas without mining activities (Balabanova et al. 2010, Razo et al. 2004, Liu et al. 2005, Liu et al. 2010, Bi et al. 2006).

Researchers worldwide have carried out studies of the distribution of TEs in different tissues of crops (Funtua et al. 2014, Hu et al. 2014, Rahman et al. 2014). TE accumulation in plants depends on plant species, plant tissues, TE species, the efficiency of different plants to take up metals and soil-to-plant bioaccumulation factors (Rattan et al. 2005, Liao et al. 2016). Wang et al. (2017) indicated that wheat was more likely to accumulate TEs than maize. Similarly, the TE contents in wheat and barley were higher than those in maize (Pruvot et al. 2006) and the mean value of TEs in rice was higher than maize in the edible part (Zarcinas et al. 2004). Chen et al. (2016) indicated that the transferability of $\mathrm{Cu}, \mathrm{Pb}, \mathrm{Zn}$ and $\mathrm{Cd}$ in a soil-rice system was stronger than those in soil-wheat and soil-canola systems. Cadmium had 
a stronger transfer capacity from soil to crops and the root acted as a barrier for $\mathrm{Pb}$ uptake. The heavy metal uptake by plants shows the greatest accumulation of $\mathrm{Cu}, \mathrm{Cr}$ and $\mathrm{Pb}$ in the roots, $\mathrm{Cd}$ in the leaves, and $\mathrm{Zn}$ in the seeds of rice (Fazeli et al. 1998). A large proportion of TEs easy accumulates in the metabolic organ, but a small amount accumulates in the vegetative organs. Nan et al. (2002) found that the order of translocation ratios of $\mathrm{Cd}$ and $\mathrm{Zn}$ in different tissues of maize and wheat were root $>$ stem $>$ grain. Therefore, the accumulative situation in crops was dissimilar among the investigated TEs.

A series of studies have been carried out in the Xingren coalmine area in southwest Guizhou province, China. Most studies have focused on the occurrence and enrichment of toxic elements in coals (Ding et al. 1999, Yang et al. 2006, Zhao et al. 1998, Yang et al. 2006), environmental geochemical characteristics (Yang \& Liu, 1997, Qu et al. 2016), soil pollution and risk assessment in the vicinity of the mine (Qin et al. 2016) and water environment chemistry (Wu et al. 2009, Sun et al. 2013, Tang et al. 2009). Due to the exposure and accumulation of TEs, the health risk to local people is associated with crops grown in the polluted area. A study focused on the potential health risks of the TEs in soil and brown rice from Hunan province of China indicated that Cd had greater transferability from soil to the plant than other elements (Zeng et al. 2015). Meanwhile, the research shows that long-term exposure to TEs through brown rice consumption poses both potential non-carcinogenic and carcinogenic health risks to the local residents (Zeng et al. 2015). Nevertheless, due to the limited assessments of metal pollution and health risks in Xingren, research gaps remain between the TE levels and accumulation characteristics in soil-crop systems.

The objective of this study was to analyse the content of TEs in soil and crop tissues, to evaluate the soil toxic element pollution and to comprehensively understand the pollution of toxic elements in the study area. The representative farmland soil-crop (rice, maize and Coix lacryma-jobi L.) systems of Xingren were selected since they are the daily diet for the local people. The risk of crop intake was evaluated by the target risk coefficient, which provides a reference for the food safety of the residents in the mining area.

\section{MATERIALS AND METHODS}

\section{Study Area}

Xingren county $\left(104^{\circ} 54^{\prime}-105^{\circ} 34^{\prime} \mathrm{E} ; 25^{\circ} 16^{\prime}-25^{\circ} 48^{\prime} \mathrm{N}\right)$ is located in the southwest of Guizhou Province, China. This area has a subtropical humid climate with an annual average rainfall of 1300 1450 mm and monthly rainfall from May to October greater than $100 \mathrm{~mm}$. The coal resource from the Xingren coalfield is plentiful and thus Xingren is listed as being one of 200 major coal-producing counties in China. The large numbers of high-coal mining operations caused environmental deterioration during the 1980s and 1990s. Although the mining activities in the high-arsenic coal area have been prohibited in 1994, there are still abandoned coalmines and coal gangue across the county. In particular, the acid wastewaters, which come into being through the migration of dust and rain leaching, are the main source of TE pollution for farmland. The major source of income for local residents is growing crops, which include rice, maize and Coix lacryma-jobi L., in the study area.

\section{Sampling and Preparation}

Sampling was carried out in October 2015. There were 67 sample sites and 8 10 soil and 3 5 plant samples were collected from each (Fig. 1). The soil was prepared by first randomly collected samples from a depth of 0-20 cm. All the samples were stored in clean polyethylene plastic bags to avoid further contamination and transported to the laboratory immediately. All soil samples were air-dried at room temperature $\left(20-25^{\circ} \mathrm{C}\right)$. Stones, plant roots and other debris were removed and then the soil was sieved through a nylon sieve (pore size $2 \mathrm{~mm}$ ). Crop samples were washed with purified deionised water $(18.2 \mathrm{M} \Omega \cdot \mathrm{cm})$ and dried overnight at $105^{\circ} \mathrm{C}$ for $2 \mathrm{~h}$, then at $75^{\circ} \mathrm{C}$ to a constant weight. After drying, the samples were crushed with a porcelain mortar and pestle and then sieved through a 2-mm nylon sieve. Portions of all samples were ground in an agate grinder and passed through a $0.149-\mathrm{mm}$ sieve to further remove impurities. The prepared samples were stored in airtight Ziploc bags at $20^{\circ} \mathrm{C}$ for laboratory analysis.

\section{Sample Testing and Quality Assurance}

Soil samples $(200 \mathrm{mg})$ were digested with $10 \mathrm{~mL}$ of concentrated $\mathrm{HNO}_{3}-\mathrm{HClO}_{4}$ in a 9:4 ratio at $160^{\circ} \mathrm{C}$ and then the levels of TEs ( $\mathrm{Pb}, \mathrm{Cd}, \mathrm{Cr}, \mathrm{Zn}$ and $\mathrm{Cu}$ ) were determined. Additionally, As was extracted using 50 vol\% aqua-regia $\left[\mathrm{HNO}_{3}(68\right.$ mass \%): $\mathrm{HCl}(37$ mass\% $)=1: 3]$. Plant samples were put in an airtight polytetrafluoroethylene tube and acidic mixture $\left(\mathrm{HNO}_{3}-\mathrm{H}_{2} \mathrm{O}_{2}\right.$ in a 3:1 ratio) was added for digestion on a fully automatic digestion instrument (Mars 6, CEM, USA). The total TE ( $\mathrm{Pb}, \mathrm{Cd}, \mathrm{Cr}, \mathrm{Zn}, \mathrm{Cu}$ and $\mathrm{As}$ ) concentrations were determined by an atomic absorption spectrometer (ZEEnit700P®, Analytikjena, Germany). The instrumental parameters of the atomic absorption spectrometer for determination of $\mathrm{Pb}, \mathrm{Cd}, \mathrm{Cr}, \mathrm{Zn}$ and $\mathrm{Cu}$ are given in Table 1 and the atomisation program is presented in Table 2 .

Arsenic was analysed using an atomic fluorescence 


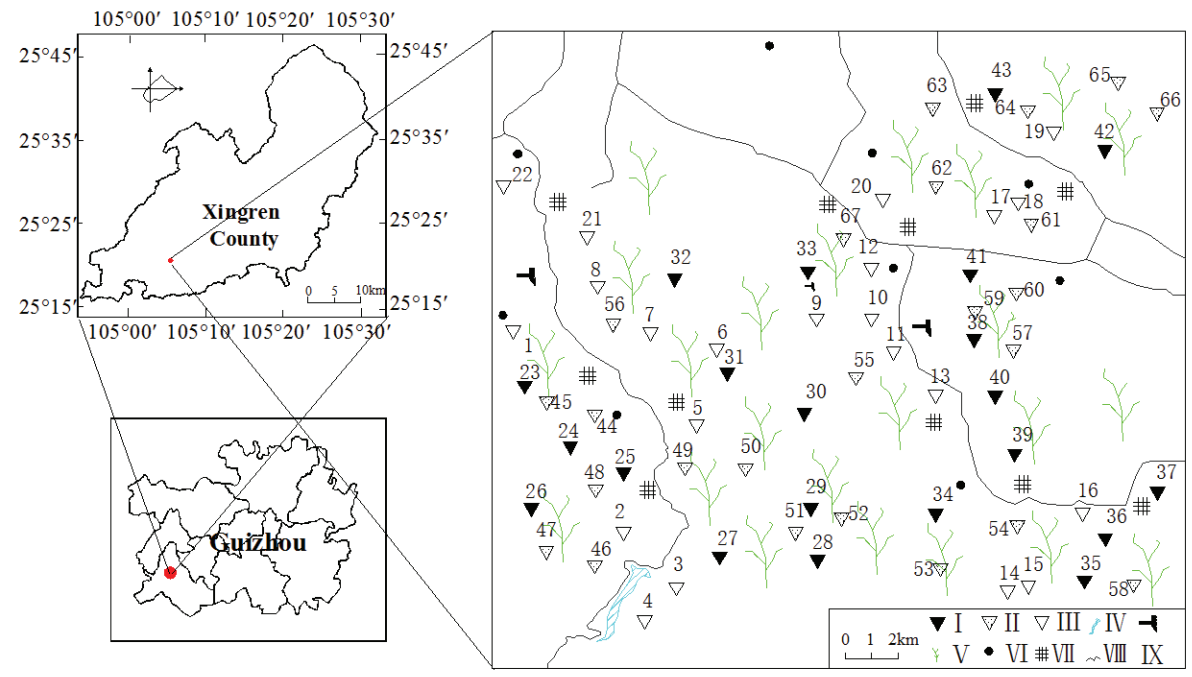

Fig. 1: Sampling location and the study area site (I Soil/maize, II Soil/Coix lacryma-jobi L., III Soil/rice, IV Water, V Crops, VI Country, VII Tailings, VIII Road, IX coal mine).

spectrometer (AFS-933, Beijing Titan, China). The test conditions for As were: wavelength $197.3 \mathrm{~nm}$; negative high voltage $270 \mathrm{~V}$; total current $60 \mathrm{~mA}$; complement cathodes 30 $\mathrm{mA}$; atomiser height $8 \mathrm{~mm}$. The digesting reagents were of analytical grade and purified deionised water $(18.2 \mathrm{M} \Omega \cdot \mathrm{cm})$ was used for dilution.

The accuracy of the measurements was verified using the national standard reference materials from the National Research Centre (Beijing, China): GBW07405 and GBW07454 for soil samples; GBW07603 for plant samples. Addition one duplicate of five samples were used for quality control.
Blanks were used for background correction and control deviation of two blanks under $20 \%$. The deviation of duplicate measurement results was within the tolerance range $(<5 \%)$.

\section{Evaluation Methods}

Geo-accumulation index: The geo-accumulation index $\left(I_{\text {geo }}\right)$ was used to evaluate the degree of anthropogenic- or geogenic-induced accumulated pollution (Bhutiani et al. 2017). The index reflects the natural variation of the TE distribution and can estimate the impact of human activities on the environment. $I_{g e o}$ is widely used to investigate quantitative

Table 1: Instrumental parameters for atomic absorption spectrophotometry analysis for determination of TEs elements.

\begin{tabular}{|c|c|c|c|c|c|}
\hline \multirow{2}{*}{ Parameter } & \multicolumn{4}{|c|}{ Element } & \multirow[b]{2}{*}{$\mathrm{Cu}$} \\
\hline & $\mathrm{Pb}$ & $\mathrm{Cd}$ & $\mathrm{Cr}$ & $\mathrm{Zn}$ & \\
\hline Wavelength (nm) & 283.3 & 228.8 & 357.9 & 213.9 & 324.8 \\
\hline Slit width (nm) & 0.5 & 0.5 & 0.8 & 0.5 & 0.8 \\
\hline Lamp type & $\mathrm{HCl}$ & $\mathrm{HCl}$ & $\mathrm{HCl}$ & $\mathrm{HCl}$ & $\mathrm{HCl}$ \\
\hline Lamp current (mA) & 2 & 2 & 4 & 2 & 2 \\
\hline
\end{tabular}

Table 2: Temperature programme for atomic absorption spectrophotometry for the determination of TEs elements.

\begin{tabular}{|c|c|c|c|c|c|c|c|c|c|c|c|c|c|c|c|}
\hline \multirow[b]{2}{*}{ Step } & \multicolumn{3}{|c|}{$\mathrm{Pb}$} & \multicolumn{3}{|c|}{$\mathrm{Cd}$} & \multicolumn{3}{|c|}{$\mathrm{Cr}$} & \multicolumn{3}{|c|}{$\mathrm{Zn}$} & \multicolumn{3}{|c|}{$\mathrm{Cu}$} \\
\hline & $\begin{array}{l}\text { Temp } \\
{ }^{\circ} \mathrm{C}\end{array}$ & $\begin{array}{l}\text { Ramp } \\
\text { (S) }\end{array}$ & $\begin{array}{l}\text { Hold } \\
\text { (S) }\end{array}$ & $\begin{array}{l}\text { Temp } \\
{ }^{\circ} \mathrm{C}\end{array}$ & $\begin{array}{l}\text { Ramp } \\
\text { (S) }\end{array}$ & $\begin{array}{l}\text { Hold } \\
\text { (S) }\end{array}$ & $\begin{array}{l}\text { Temp } \\
{ }^{\circ} \mathrm{C}\end{array}$ & $\begin{array}{l}\text { Ramp } \\
\text { (S) }\end{array}$ & $\begin{array}{l}\text { Hold } \\
\text { (S) }\end{array}$ & $\begin{array}{l}\text { Temp } \\
{ }^{\circ} \mathrm{C}\end{array}$ & $\begin{array}{l}\text { Ramp } \\
\text { (S) }\end{array}$ & $\begin{array}{l}\text { Hold } \\
\text { (S) }\end{array}$ & $\begin{array}{l}\text { Temp } \\
{ }^{\circ} \mathrm{C}\end{array}$ & $\begin{array}{l}\text { Ramp } \\
\text { (S) }\end{array}$ & $\begin{array}{l}\text { Hold } \\
\text { (S) }\end{array}$ \\
\hline Drying & 110 & 5 & 10 & 110 & 6 & 20 & 110 & 5 & 10 & 110 & 5 & 10 & 110 & 5 & 10 \\
\hline Pyrolysis & 800 & 300 & 10 & 500 & 300 & 10 & 1300 & 300 & 10 & 650 & 50 & 20 & 1100 & 300 & 10 \\
\hline Atomization & 2000 & 1600 & 4 & 1500 & 1500 & 3 & 2300 & 1500 & 5 & 2150 & 1500 & 3 & 2100 & 1500 & 4 \\
\hline Clean-out & 2450 & 500 & 4 & 2450 & 500 & 4 & 2450 & 500 & 4 & 2450 & 500 & 4 & 2450 & 500 & 4 \\
\hline
\end{tabular}


indicators of TEs pollution in sediments and soil (Förstner et al. 1993). The formula is:

$$
I_{g e o}=\log _{2}\left(\frac{\mathrm{C}_{\mathrm{n}}}{1.5 \mathrm{~B}_{\mathrm{n}}}\right)
$$

Where, $I_{g e o}$ is the index of geo-accumulation for an element in soil samples; and are the determined concentration of the metals in the target and reference areas, respectively. The values used were the average background values of TEs in Guizhou soil: $\mathrm{As}=20.00 \mathrm{mg} / \mathrm{kg}, \mathrm{Cr}=95.90 \mathrm{mg} / \mathrm{kg}, \mathrm{Pb}=$ $35.20 \mathrm{mg} / \mathrm{kg}, \mathrm{Zn}=99.50 \mathrm{mg} / \mathrm{kg}, \mathrm{Cd}=0.66 \mathrm{mg} / \mathrm{kg}$ and $\mathrm{Cu}=$ $32.00 \mathrm{mg} / \mathrm{kg}$ (MEPPRC 1990). $\mathrm{I}_{\text {geo }}$ and the classification of pollution level (Müller 1969) are given in Table 3.

Potential Ecological Risk: The Potential Ecological Risk Index (RI) evaluates the ecological degree for toxins and toxic elements in soils (Häkanson 1980) that could be toxic for biological species (Yisa et al. 2012). As one of the most common risk assessment methods of toxic element pollution for soil, it not only reflects the impact of a single pollutant in a particular environment but also reflects the comprehensive impact of a variety of pollutants. The formulas are shown as follows:

$$
\begin{gathered}
E_{r}^{i}=T_{r}^{i} \cdot \frac{C_{i}}{C_{n}^{i}} \\
R I=\sum E_{r}^{i}=\sum T_{r}^{i} \cdot C_{f}^{i}
\end{gathered}
$$

Where, is the pollution coefficient for a certain element, which reflects the pollution level of a single TE (Zhuang \& Gao 2014). is the concentration of the $i$ th toxic metal in soil, and indicates the reference background concentration of toxic elements in the soils of Guizhou Province (MEPPRC 1990). is the potential ecological risk coefficient of the particular TE. is the toxic-response factor for element $i$. According to Häkanson (1980), is set as follows: $\mathrm{Pb}=5$, $\mathrm{Cd}=30, \mathrm{Cr}=2, \mathrm{Zn}=1, \mathrm{Cu}=5$ and $\mathrm{As}=10$. The potential ecological risk index was classified into five categories (Table 4) (Häkanson 1980, Zhuang \& Gao 2014).

There were some differences with the classical Häkanson potential ecological hazard index method (Häkanson 1980). In the studies of Häkanson (1980) and Zhuang \& Gao (2014), the first-stage upper limit of the is obtained by the non-polluted pollution coefficient $(=1)$ multiplied by the maximum toxicity coefficient in the reference pollutant. In this paper, the value of $\mathrm{Cd}$ is the largest one among the six of TEs, as $=30$. From this, the first grading criterion of is 30 , and the other criterion is multiplied by 2 on the previous stage (Li et al. 2015).

From Formula (3), RI is related to the type and quantity of pollutants. Specifically, the pollutants constituted more complex have stronger toxicity (the larger), the greater the RI value. Thus, it must be considered that appropriate adjustment the type and quantity of pollutants when using the RI ecological risk assessment.

Using Häkanson's first-level classification limit (150) and the total toxicity factor of eight pollutants (133) to get the unit toxicity coefficient (1.13). Taken unit toxicity coefficient (1.13) to multiply total toxicity coefficient (53) of six $\mathrm{TE}$, and round the decimal to get the first limit of RI (about 60 ), the other criterion was multiplied by 2 on the previous stage. The classification criteria for the assessment of the potential ecological risk of TEs in soils are given in Table 4. It is different from the Häkanson's classification.

Plant enrichment is closely related to plant species, soil substrate, and TEs' categories. The bioaccumulation factor or transfer factor $(\mathrm{BAF} / \mathrm{TF})$ is usually used to characterise plant TE accumulation (Khan et al. 2010), which reflects the plant ability for metal storage in roots and/or translocation to aerial organs. The BAF was calculated as follows:

$$
\mathrm{BAF}=\frac{\mathrm{C}_{r}}{\mathrm{C}_{s}}
$$

Table 3: Index of Geo-accumulation $\left(\mathrm{I}_{\text {geo }}\right.$ ) and classification of pollution level (Müller 1969).

\begin{tabular}{|lllllll|}
\hline Degree of pollution & Clean & $\begin{array}{l}\text { Light } \\
\text { Pollution }\end{array}$ & $\begin{array}{l}\text { Partial } \\
\text { contamination }\end{array}$ & Contamination & $\begin{array}{l}\text { Emphasis on } \\
\text { pollution }\end{array}$ & $\begin{array}{l}\text { Heavy } \\
\text { pollution }\end{array}$ \\
\hline$I_{\text {geo }}$ & $I_{\text {geo }} \leq 0$ & $0<I_{\text {geo }} \leq 1$ & $1<I_{\text {geo }} \leq 2$ & $2<I_{\text {geo }} \leq 3$ & $3<I_{\text {geo }} \leq 4$ & $4<I_{\text {geo }} \leq 5$ \\
Grade & 0 & 1 & 2 & 3 & 4 & 5 \\
\hline
\end{tabular}

Table 4: Grading standards of potential ecological risk of TEs in soils.

\begin{tabular}{|lllll|}
\hline Degree & Low & Moderate & Considerable & High \\
\hline Eir & $\leq 30$ & $30 \sim 60$ & $60 \sim 120$ & $120 \sim 240$ \\
RI & 60 & $60 \sim 120$ & $120 \sim 240$ & $\geq 240$ \\
\hline
\end{tabular}




$$
\mathrm{TF}=\frac{\mathrm{C}_{t}}{\mathrm{C}_{r}}
$$

Where, $\mathrm{C}_{t}$ represents the TE concentration in tissues (stalk, leaf, husk or edible parts) of crops; $\mathrm{C}_{r}$ represents the concentration in the root; $\mathrm{C}_{s}$ represent concentration in soils on a dry-weight basis.

The target hazard quotient (THQ) is a health risk assessment model recommended by the US Environmental Protection Agency (US EPA 1997). The health risks from consumption of crops depend on the level of exposure and the amount of absorption by local inhabitants. The estimated risk using the THQ is based on the equation below (US EPA 1997, Bhatti et al. 2017).

Where, $\mathrm{C}_{\mathrm{C}}$ is the metal concentration in crops $(\mathrm{mg} / \mathrm{kg})$; $\mathrm{D}_{\mathrm{F}}$ is food ingestion (g/person/d); $\mathrm{B}_{\mathrm{W}}$ is the average adult body weight $(60 \mathrm{~kg})$; RfD is the oral reference dose $(\mathrm{mg} /$ $\mathrm{kg} / \mathrm{d})$.

$$
\mathrm{THQ}=\frac{\mathrm{C}_{\text {crop }} \times \mathrm{D}_{\text {foodintake }} \times \mathrm{EF} \times \mathrm{ED}}{\mathrm{B}_{\mathrm{w}} \times \mathrm{AT} \times \mathrm{RfD}}
$$

Where, $\mathrm{C}_{\text {crop }}$ is the metal concentration in food $(\mathrm{mg} / \mathrm{kg})$; $\mathrm{D}_{\text {food intake }}$ is food ingestion ( $\mathrm{g} /$ person/d); BW is the average body weight, adult $(60 \mathrm{~kg})$; EF is exposure frequency (365 days/year); ED is exposure duration (70 years); AT is averaging time for noncarcinogens (365 days/year $\times$ number of exposure years, assuming 70 years in this study); RfD is the oral reference dose $(\mathrm{mg} / \mathrm{kg} / \mathrm{d})$. Oral reference doses were $3.5 \times 10^{-3}, 1.0 \times 10^{-2}, 1.5,0.3,4.0 \times 10^{-2}$ and $3.0 \times 10^{-4} \mathrm{mg} / \mathrm{kg} / \mathrm{d}$ for $\mathrm{Pb}, \mathrm{Cd}, \mathrm{Cr}, \mathrm{Zn}, \mathrm{Cu}$ and As respectively (US EPA 1997).

Considering the literature (US EPA 1997, Bhatti et al. 2017, Fang et al. 2015, Du et al. 2013, Zeng et al. 2015, Wang et al. 2016) and the US EPA exposure factors handbook, it was determined that the adult intake in this area was $0.25,0.15$ and $0.20 \mathrm{~kg} / \mathrm{person} / \mathrm{d}$ for rice, maize and Coix lacryma-jobi L., respectively. If the THQ is $\geq 1$, the exposed population is likely to experience serious health risks and if the level of the THQ is $<1$, the risk associated with exposure to the metal is negligible.

The potential impact of TEs on human health is generally a combined effect of a variety of elements (Bhatti et al. 2017).
To assess the combined effect of more than one element, Total THQ (TTHQ) is calculated by the following modified equation (US EPA 1997):

$\mathrm{TTHQ}($ crop $)=\sum \mathrm{THQ}_{\mathrm{M}}=\mathrm{THQ}_{\mathrm{M} 1}+\mathrm{THQ}_{\mathrm{M} 2}+\cdots+\mathrm{THQ}_{\mathrm{Mn}} \ldots$ (7)

When TTHQ $\leq 1$, it means there is no significant negative impact; when $1 \leq$ TTHQ $<10$, the TEs may be potential non-carcinogenic health risks, and when TTHQ $>10$, the presence of TEs will cause chronic toxic effects.

The data were processed in Excel 2007 for preliminary data processing. Statistical analyses were performed with the Statistical Package for the Social Sciences (SPSS 18.0). Charts and graphs were created using Origin (Origin 8.5, OriginLab) and The R Programming Language (R i386 3.4.1).

\section{RESULT AND DISCUSSION}

\section{Concentration of TEs in Crop Soils}

The soil $\mathrm{pH}$ varied between 3.95 and 6.37. The rice soil had lower $\mathrm{pH}$ compared to the two other crops. Table 5 summarises the $\mathrm{pH}$ and variation coefficient (VC, $\mathrm{SD} /$ mean) of $\mathrm{Pb}$, $\mathrm{Cd}, \mathrm{Cr}, \mathrm{Zn}, \mathrm{Cu}$ and $\mathrm{As}$ in soils from the target area. According to the soil background value of Guizhou (MEPPRC 1990), all elements in the soil were higher than the background value, especially $\mathrm{Pb}$ and $\mathrm{As}$. The mean concentrations of $\mathrm{Pb}$ $(183.11 \mathrm{mg} / \mathrm{kg})$ and $\mathrm{As}(119.03 \mathrm{mg} / \mathrm{kg})$ in rice soil were 5.2 and 5.95 times higher than the background value $(\mathrm{Pb}=35.20$ $\mathrm{mg} / \mathrm{kg}$, As $=20.00 \mathrm{mg} / \mathrm{kg}$ ), respectively. Similar results were found for maize and Coix lacryma-jobi $\mathrm{L}$. The $\mathrm{Cd}$ and $\mathrm{As}$ minimum concentrations in soils exceeded the grade II of environmental quality standard values $(\mathrm{Cd}=0.30 \mathrm{mg} / \mathrm{kg}$, As $=30 \mathrm{mg} / \mathrm{kg}$ in paddy field or $40 \mathrm{mg} / \mathrm{kg}$ in dry land) for soils of China (MEPPRC 1990); in particular, the As in paddy soil was 2.45 times above the standard value.

The mean value of $\mathrm{Pb}, \mathrm{Cd}, \mathrm{Cr}, \mathrm{Zn}, \mathrm{Cu}$ and $\mathrm{As}$ in soil exceeded the maximum permitted levels (Fig. 2). The concentrations of $\mathrm{Pb}, \mathrm{Cd}$ and As were found to be far more than the reported levels (Shen et al. 2011) in the target area, while $\mathrm{Zn}$ and $\mathrm{Cu}$ showed less difference. One reason is that the investigated area suffered sewage irrigation, as well as spraying of pesticides, manure and fertiliser, which possibly increase

Table 5: $\mathrm{pH}$ and variation coefficient (VC) of TEs in soil samples.

\begin{tabular}{|lllllllll|}
\hline Soil usage type & $\mathrm{pH}$ & Statistics & $\mathrm{Pb}$ & $\mathrm{Cd}$ & $\mathrm{Cr}$ & $\mathrm{Zn}$ & $\mathrm{Cu}$ & $\mathrm{As}$ \\
\hline Rice soil (n=22) & $3.95 \sim 6.19$ & $\mathrm{VC} / \%$ & 29.74 & 20.95 & 16.41 & 9.63 & 30.72 & 23.13 \\
Maize soil (n=22) & $4.28 \sim 6.22$ & $\mathrm{VC} / \%$ & 22.37 & 22.82 & 17.28 & 11.77 & 38.90 & 22.20 \\
Coix lacryma-jobi L. soil (n=24) & $4.35 \sim 6.37$ & $\mathrm{VC} / \%$ & 18.80 & 21.34 & 17.39 & 13.48 & 42.89 & 25.80 \\
\hline
\end{tabular}


the TE contamination compared to that of abandoned agricultural land. Another possible reason is the mining activities and factories around the study area (Li et al. 2014), which may also contribute to the TE exposure. The mean levels of $\mathrm{Pb}, \mathrm{Cd}, \mathrm{Cr}, \mathrm{Zn}$ and $\mathrm{Cu}$ in the three crops were in this order: upland $(207.89,0.89,194.00,102.52$ and $131.43 \mathrm{mg} / \mathrm{kg}$ for maize; $212.18,0.88,197.31,106.40$ and $128.01 \mathrm{mg} / \mathrm{kg}$ for Coix lacryma-jobi L.) > paddy soil (183.11, 0.78, 188.73, 97.22 and $147.10 \mathrm{mg} / \mathrm{kg}$ ). These five elements had similar trends in the maize soil and the Coix lacryma-jobi L. soil.

\section{Assessment of TE Pollution by the Index of Geo- accumulation:}

The geo-accumulation indexes calculated for the soil of the target areas are shown in Fig. 3. The mean $I_{\text {geo }}$ for toxic elements had a trend of $\mathrm{As}$ and $\mathrm{Pb}>\mathrm{Cu}>\mathrm{Cr}>\mathrm{Cd}>\mathrm{Zn}$. A similar study by Qin et al. (2016) indicated that $\mathrm{As}$ and $\mathrm{Pb}$ had relatively higher contamination levels $\left(I_{g e o} \geq 3\right)$. The result from Fig. 3. showed that $\mathrm{Zn}$ from all the soil samples was similar to the unpolluted level, $\mathrm{Cd}(86.36 \%$ soil samples for rice, $76.19 \%$ soil samples for maize, $79.17 \%$ soil samples for Coix lacryma-jobi L.) was at the clean level and $\mathrm{Cr}(90.91 \%$, 90.48\% and $95.83 \%$ for rice, maize and Coix lacryma-jobi L.) indicated light pollution, while $\mathrm{Pb}, \mathrm{Cu}$ and As indicated moderate contamination. According to the mean $I_{g e o}$, the elemental concentration in the studied soil samples could be categorised as: (1) $\mathrm{As}, \mathrm{Pb}$ and $\mathrm{Cu}$ in the moderately polluted category; the source could be coal gangue, which contains $\mathrm{Cu}$ and $\mathrm{Pb}$, and uncontrolled discarded wastewater (Qishlaqi et al. 2008); (2) Cr was in the lightly polluted category and might be mainly related to atmospheric deposition (Shi et al. 2014, Zeng \& Wu 2013); and (3) Cd and Zn were in the unpolluted category. The results are similar to those reported by Qin et al (2016) in which the contamination levels were in the order: $\mathrm{As}, \mathrm{Pb}$ and $\mathrm{Cu}>\mathrm{Cr}>\mathrm{Cd}$.

\section{Assessment of TE Pollution by Potential Ecological Risk}

According to the formulas (2-3), the ecological risk (ER) value and potential ecological risk values (RI) for each of
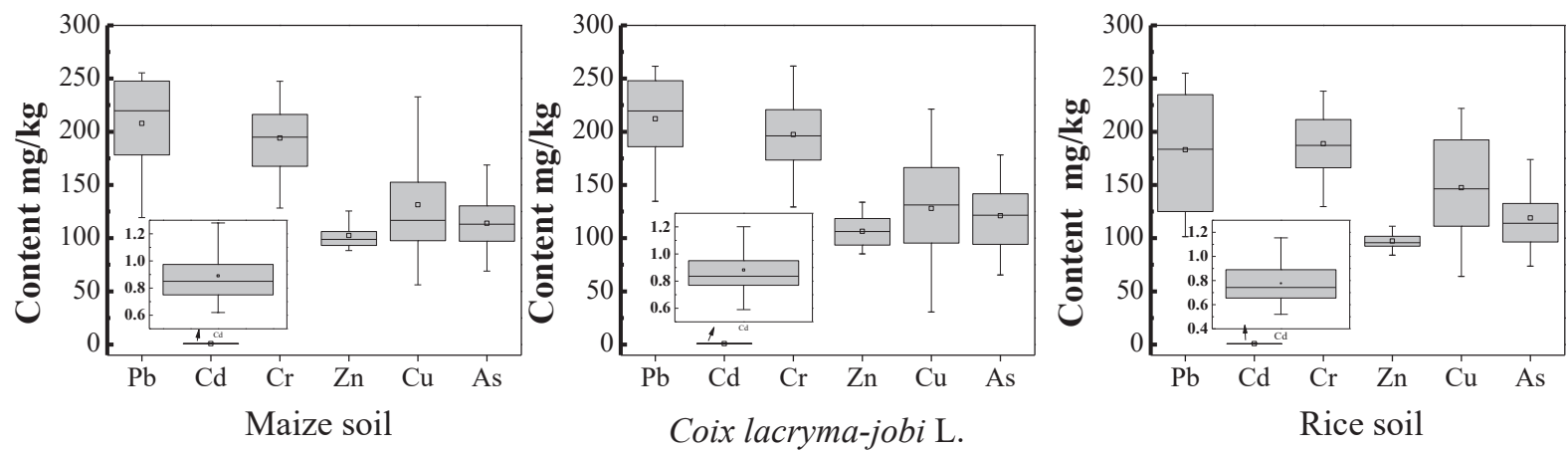

Fig. 2: Box plots for content of TEs in different type soils. ( $\mathrm{n}=67$ ) Guizhou soil background: $\mathrm{As}=20.00 \mathrm{mg} / \mathrm{kg}, \mathrm{Cr}=95.90 \mathrm{mg} / \mathrm{kg}, \mathrm{Pb}=35.20 \mathrm{mg} / \mathrm{kg}$, $\mathrm{Zn}=99.50 \mathrm{mg} / \mathrm{kg}, \mathrm{Cd}=0.66 \mathrm{mg} / \mathrm{kg}, \mathrm{Cu}=32.00 \mathrm{mg} / \mathrm{kg}$. Standards values $(\mathrm{pH}<6.5)$ were $250,0.30,200,50 \mathrm{mg} / \mathrm{kg} \mathrm{for} \mathrm{Pb}, \mathrm{Cd}, \mathrm{Zn}$ and $\mathrm{Cu} ; 250,30$ $\mathrm{mg} / \mathrm{kg}$ for $\mathrm{Cr}$ and As in paddy field, $130,40 \mathrm{mg} / \mathrm{kg}$ for $\mathrm{Cr}$ and As in dry land. (Grade II of environmental quality standards values for soils of China, GB 15618-1995).
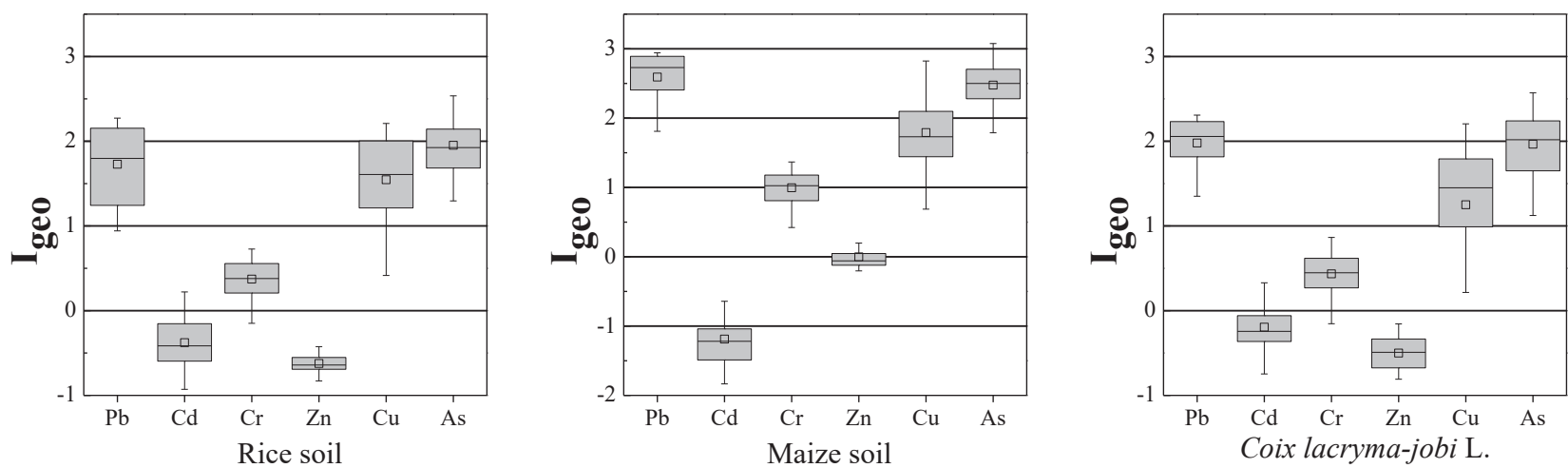

Fig. 3: Box plots for $\mathrm{I}_{\mathrm{geo}}$ of TEs in different type soils, the horizontal lines represent $\mathrm{I}_{\text {geo }}$ values of $-1,0,1,2$ and 3. (n=67). 
the studied metals are shown (individually and in total) in Fig. 4 and 5. The risk indices of the metals are in the order: As $>\mathrm{Cd}>\mathrm{Pb}>\mathrm{Cu}>\mathrm{Cr}>\mathrm{Zn}$.

The ER values for $\mathrm{Cr}$ and $\mathrm{Zn}$ were mostly at low levels, while these values were high for the other examined elements. The results indicate that the contribution of $\mathrm{Cr}$ and $\mathrm{Zn}$ to the potential ecological risk is relatively low. The sample of $\mathrm{ER}_{\mathrm{Pb}}$ in low ecological risk level (50\% of samples) and moderate ecological risk level (50\% of samples) is in equal possibility. Almost every sample of $\mathrm{ER}_{\mathrm{Cu}}$ was of low potential ecological risk. From Fig. 3, almost all the $\mathrm{ER}_{\mathrm{As}}$ and $\mathrm{ER}_{\mathrm{Cd}}$ values from the study area reached the level of moderate potential ecological risk $(30<\mathrm{ER}<60)$.

The $I_{g e o}$ result indicates that $\mathrm{Pb}$ and $\mathrm{As}$ are in a similar pollution situation. The reason why $\mathrm{ER}_{\mathrm{As}}>\mathrm{ER}_{\mathrm{Pb}}$ is that the toxic-response factor of As is double that of $\mathrm{Pb}$. Cadmium posed a moderate potential ecological risk, which differs from the $I_{g e o}$ level because the toxic-response coefficient is
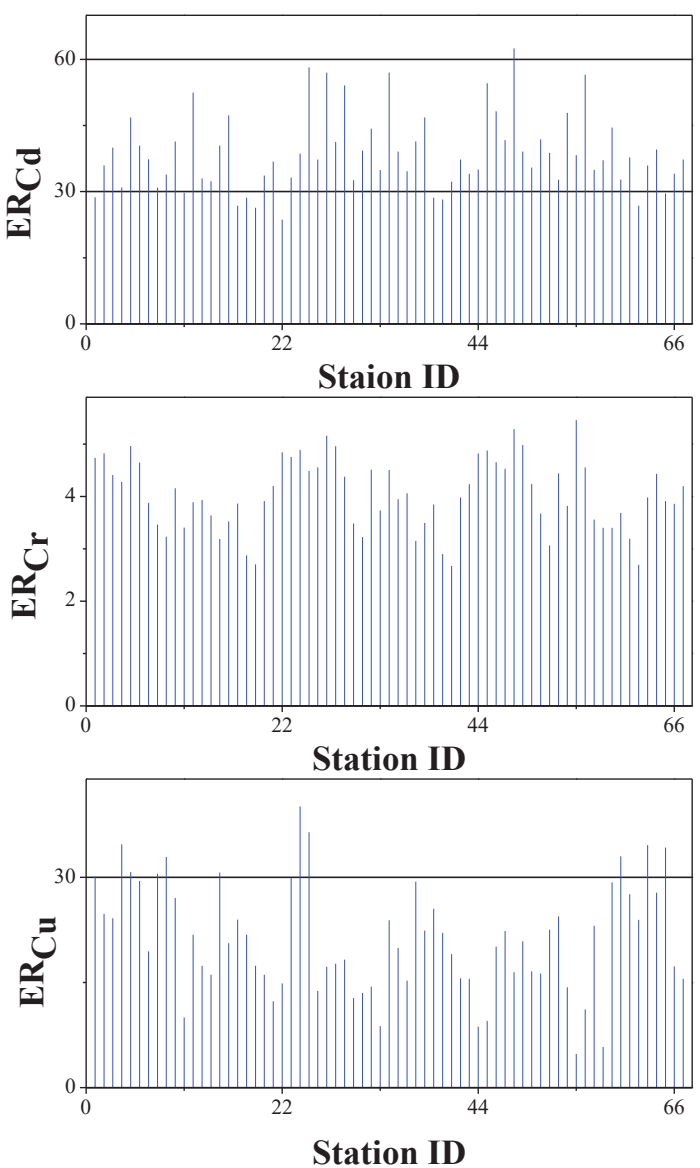

relatively high $(=30)$. The rank of the ER average of each element in the three types of land-use was similar to the results of $\mathrm{I}_{\text {geo }}$, indicating that the soil pollution impacts its ER.

Fig. 5 shows that nearly $94 \%$ of the study area reached the level of considerable potential ecological risk $(120<\mathrm{RI}$ $<240)$. The variation decreased in the order: maize (100-205) $>$ rice (97-196) > Coix lacryma-jobi L. (117-195). Average RI was highest in Coix lacryma-jobi L. followed by maize and rice. The mean and individual values showed considerable potential ecological risk due to a high level of TEs in the study area. The interaction of the six elements increases the risk of the study area and the high degree of potential ecological risk may lead to crop contamination.

It is crucial to integrate these methods to obtain more knowledge of the TEs risk in the target area due to the limitation of the current models (Zhang et al. 2012). Long-term mining activities ( $>10$ years) resulted in high arsenic levels in coalmining areas (Chen et al. 2002), which polluted the
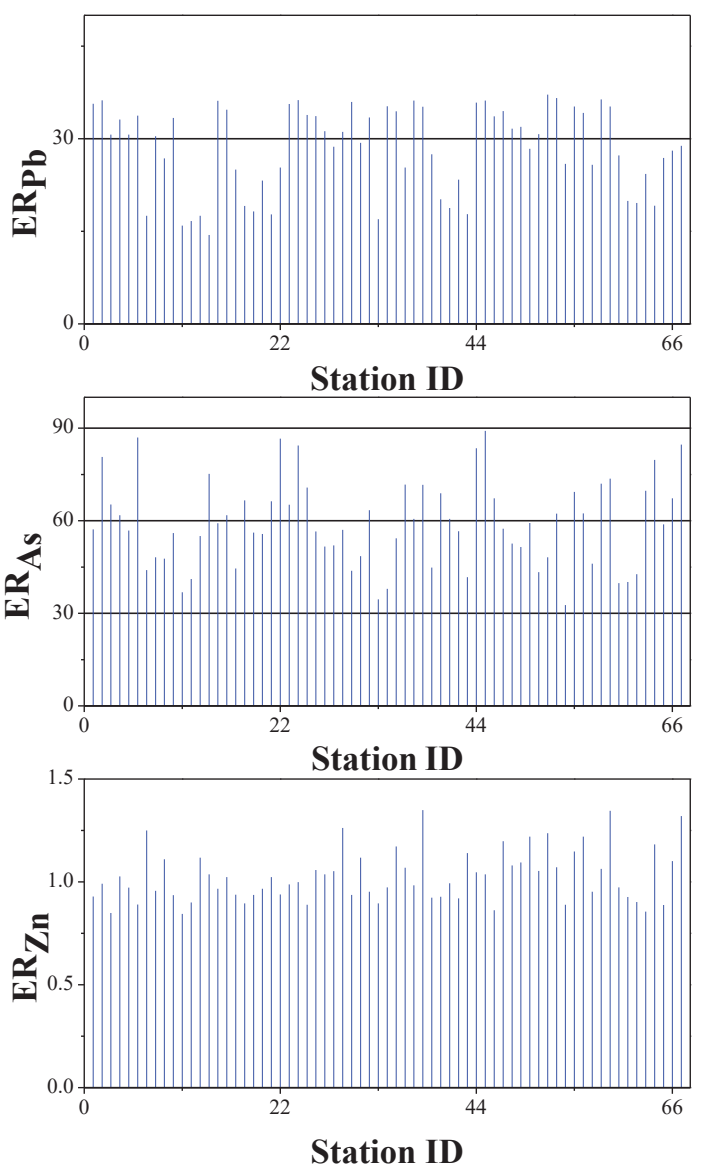

Fig. 4: The ecological risk (ER) of HMs in soil samples, the horizontal lines represent ER values of 30, 60 and 90 . (n=67 soil, rice is range 1 to 22 , maize is 23 to 43 , Coix lacryma-jobi $\mathrm{L}$. is 44 to 67 ). 
nearby water and affected ecological functions. There was moderate contamination by As and the considerable potential ecological risk is shown by merging the results of $\mathrm{I}_{g e o}$ and the potential ecological risk.

\section{Assessment of TE Concentration in Crops}

The concentration of TEs in each plant portion is presented in Fig. 6. TEs were widely distributed in different parts of the plant and the TEs in root were significantly higher than in other parts (Bose \& Bhattacharyya 2008). It is important to focus on the TE content of the edible part because it is the main source of dietary exposure (Khan et al. 2015). The mean concentration of $\mathrm{Pb}(0.12 \mathrm{mg} / \mathrm{kg}), \mathrm{Cd}(0.07 \mathrm{mg} / \mathrm{kg}), \mathrm{Cr}(0.64$ $\mathrm{mg} / \mathrm{kg}), \mathrm{Cu}(1.58 \mathrm{mg} / \mathrm{kg})$ and $\mathrm{As}(0.17 \mathrm{mg} / \mathrm{kg})$ in the edible part of rice were less than other organisation (the minimum of other organisation: $0.75,0.08,1.44,1.80,0.65 \mathrm{mg} / \mathrm{kg}$ ). Similar results were found in maize and Coix lacryma-jobi $\mathrm{L}$.

Analysis of the levels of the elements in three crops (rice, maize and Coix lacryma-jobi L.) showed that TEs (except $\mathrm{Zn}$ ) were highest in the root and lowest in the edible part. However, $\mathrm{Zn}$ showed a different trend. $\mathrm{Zn}$ was higher in the stalk and leaf for rice, in the leaf and husk for maize, and the leaf and edible parts for Coix lacryma-jobi L. Compared with rice and maize, the edible part of Coix lacryma-jobi $\mathrm{L}$. has a relatively strong capacity for $\mathrm{Zn}$ storage. According to the maximum permitted level of contaminants in food set by the Ministry of Heath of the People's Republic of China (MHPRC 2012), the mean value of the edible portions of the three crops was below the threshold of safety value for $\mathrm{Pb}, \mathrm{Cd}, \mathrm{Cr}, \mathrm{Zn}, \mathrm{Cu}$ and $\mathrm{As}(0.20,0.10,1.00,50.00,10.00$ and $0.20 \mathrm{mg} / \mathrm{kg}$ ). The concentrations of $\mathrm{Pb}$ in the edible part were highest in Coix lacryma-jobi L. $(0.14 \mathrm{mg} / \mathrm{kg})$ and lowest in maize $(0.10 \mathrm{mg} / \mathrm{kg})$, which was similar to
$\mathrm{Cr}$ and As. Zinc was highest in Coix lacryma-jobi L. (10.91 $\mathrm{mg} / \mathrm{kg}$ ) and lowest in rice $(6.24 \mathrm{mg} / \mathrm{kg})$, which was the same as $\mathrm{Cd}$ and $\mathrm{Cu}$.

Compared TEs content of three crops show that As and $\mathrm{Cd}$ were highest (lowest) in rice (maize) and maize (rice), respectively; $\mathrm{Cu}$ was higher in Coix lacryma-jobi L. There was an interspecific difference among crops. As and $\mathrm{Pb}$ content was high and matched the geo-accumulation index evaluation result. Compared to the concentration of $\mathrm{Cd}$ in soil, the concentration in crops was at a higher level.

\section{The TF and BAF of the Crops}

To assess the transfer of TEs from soil to crops, the transfer factor (TF) and bioaccumulation factor (BAF) were calculated (Fig. 7). The BAF and TF of different TEs in crops were dissimilar. The capacity of plants to uptake toxic elements is different and the same toxic element can be accumulated in different ratios in various plant species (Singh et al. 2010). The transport and enrichment ability of TEs was higher in the aerial parts than the underground parts of the crops. The reason is that aerial parts of plants mainly consist of metabolic organs and biomass is higher than underground.

Transfer factors of the edible parts (leaf, stalk and husk) for TEs decreased in the order $\mathrm{Cd}>\mathrm{Zn}>\mathrm{Cu}>\mathrm{Cr}>\mathrm{As}>$ $\mathrm{Pb}$. The $\mathrm{TF}_{\mathrm{Pb}}$ values (except above total) was lower than 0.01 for the three cultivation systems. The possible reason was that the root hinders uptake of $\mathrm{Pb}$ (Cui et al. 2014). The $\mathrm{BAF}_{\text {root }}$ (except As of maize and Pd of Coix lacryma-jobi $\mathrm{L}$ ) decreased in the order $\mathrm{Cd}>\mathrm{Cu}>\mathrm{Zn}>\mathrm{As}>\mathrm{Cr}>\mathrm{Pb}$, which is similar to the study by Chen et al. (2016) in rice of the Yangtze River Delta region. $\mathrm{The}_{\mathrm{TF}}$ and $\mathrm{TF}_{\mathrm{As}}$ of the aerial part (except As of rice) were in contrast to those of the root ( $\mathrm{Zn}>\mathrm{Cu}$ and $\mathrm{Cr}>\mathrm{As})$. This result shows that the aerial parts

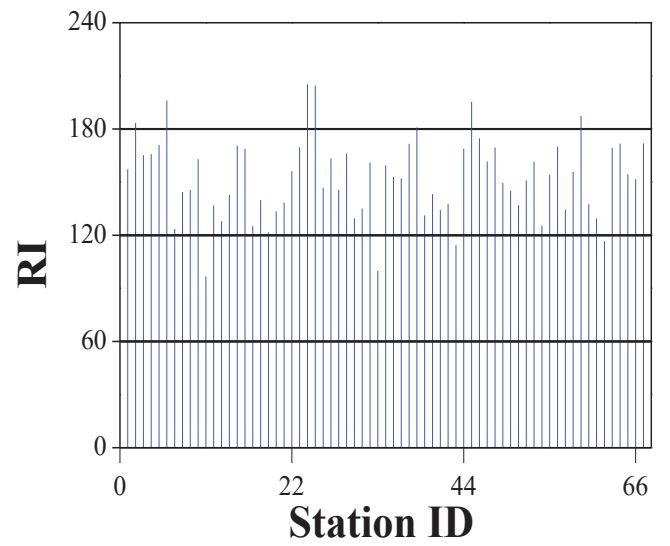

Fig. 5: The potential ecological risk index (RI) of TEs in soil samples, the horizontal lines represent RI values of 60, 120 and 180 . (n=67 soil, rice is range 1to 22, maize is 23 to 43 , Coix lacryma-jobi L. is 44 to 67.$)$ 
could absorb the $\mathrm{Zn}$ by the root and hinder the migration of As. BAF (TF) of Cd was significantly higher than other elements. Cd performed a higher capacity of transportation inside the plant and the soil-crop system, which may explain that why soil evaluated in clean level has a potential risk. These results indicate that despite $\mathrm{Cd}$ in soil was not polluted $\left(I_{\text {geo }}<0\right)$, but the ability of three crops for the absorption of $\mathrm{Cd}$ was relatively strong. BAFs of $\mathrm{Zn}$ were slightly lower than those of $\mathrm{Cd}$. The synergism between $\mathrm{Cd}$ and $\mathrm{Zn}$ enhances the efficiency of each other's transfer (Nan et al. 2002). In the rice-soil system, $\mathrm{BAF}_{\mathrm{Zn}}$ and $\mathrm{BAF}_{\mathrm{As}}$ showed the highest values, which were different depending on the soil type (dry land $>$ paddy field). These data indicate that the accumulation of TEs in crops is not only influenced by soil concentration, but also by physical and chemical properties of the soil or other factors. For instance, the equilibrium $\mathrm{pH}$ value $(<4)$ could affect toxic elements sorption and desorption on soil components thus affecting the migration of metals (Najafi \& Jalali 2015). Most soils of the target area are acidic, which may promote the migration of toxic elements from soil to crop (Chen et al. 2016). Possible reasons include (1) rice having a strong transferability for $\mathrm{Zn}$ and As; (2) water evaporates out cause the $\mathrm{pH}$ to decrease during the maturation period (Shamshuddin et al. 2014), which may lead to metal desorption and metal ions being released into the soil solution (Chen et al. 2016).

The BAF and TF of each metal were dependent on the crop type and species. The bioaccumulation of toxic elements is different for different plant species, which is reflected by differences in their growth, reproduction, occurrence and survival in the metal-contaminated soil (Khan et al. 2015). Notably, different plant species possess different tolerance to the same pollutant under the same conditions. This difference may be explained by the different mechanisms and efficiency in the elemental uptake of plant species (Garty 2001). The BAF (TF) of TEs (except for $\mathrm{Zn}$ ) in the three crops can be divided into three levels: root $>$ stalk and leaf $>$ husk and edible parts, while the $\mathrm{Zn}$ is disordered. Fig. 6 shows that the accumulation ability of edible part is highest in Coix lacryma-jobi L (except $\mathrm{Cr}$ ) compared to other crops. The TF of As in each part of rice is higher than other crops in this study, which represent that As was easily absorbed by
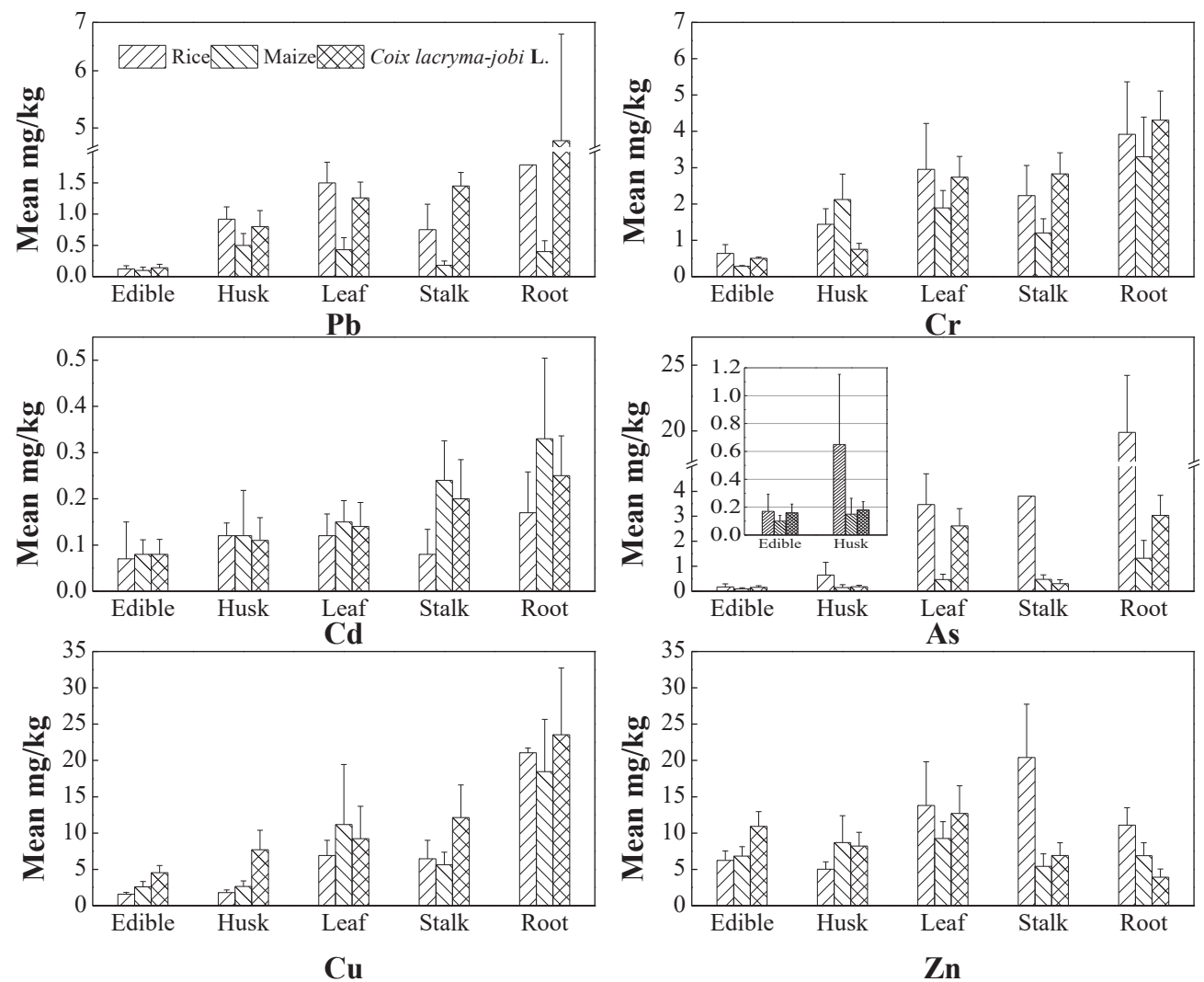

Fig. 6: The concentrations of TEs in each part of crop samples $(\mathrm{mg} / \mathrm{kg})$. 
the rice. Maize had relatively lower enrichment and transport capacity compared to rice and Coix lacryma-jobi $\mathrm{L}$, except for $\mathrm{Cd}$. Combining the $\mathrm{BAF}$ and $\mathrm{TF}_{\text {above total }}$ it was found that the absorption of $\mathrm{Cu}(\mathrm{Zn})$ of Coix lacryma-jobi $\mathrm{L}$. (rice) was higher than other plants.

\section{Correlation Coefficient Between TEs in Soil and Crop Tissue}

As shown in Fig. 8, the $r$-values were found to be significant
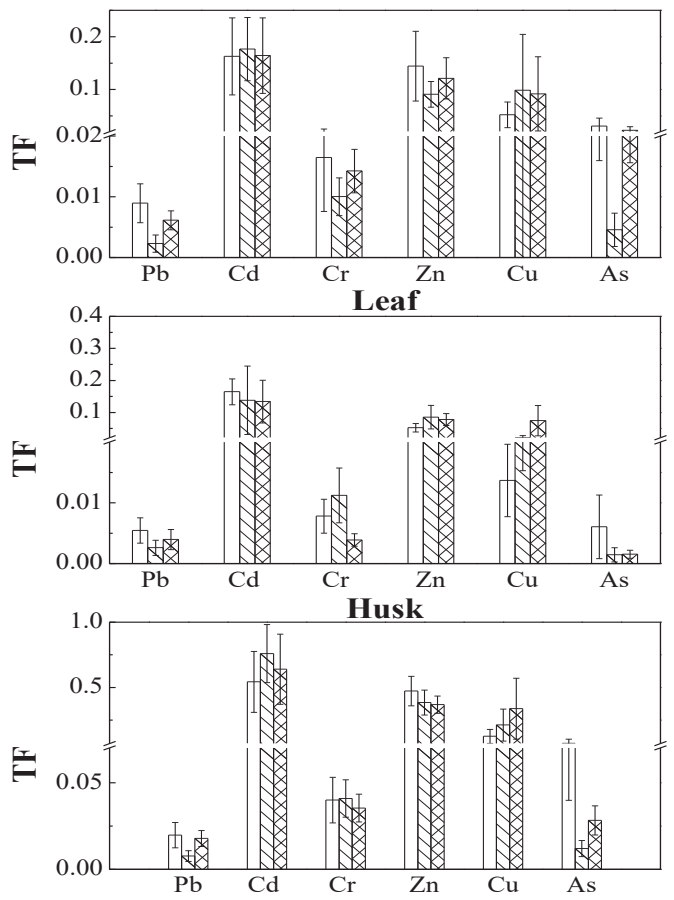

Above total $(\mathrm{p}<0.05)$. Thus, all the observed correlations were not high. The $r$-value depicted the strongest positive correlation as being between root and soil. The most significant positive correlation was observed for As of rice, $\mathrm{Cu}$ of maize and $\mathrm{Zn}$ of Coix lacryma-jobi L. ( $r$-values of $0.415,0.437$ and 0.413 , respectively). TEs in root were positively correlated with soils, showing an increase in the concentration of one metal with a decrease in the concentration of other metals. No significant positive or negative correlation was observed
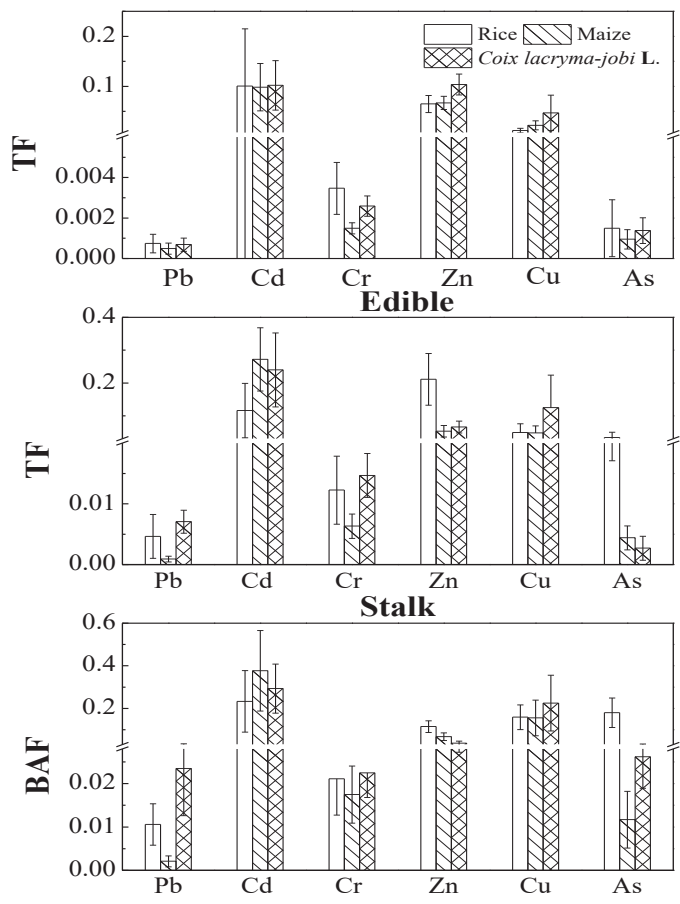

Root

Fig. 7: Transfer factor and bioaccumulation factor of TEs in the three soil-crop systems.

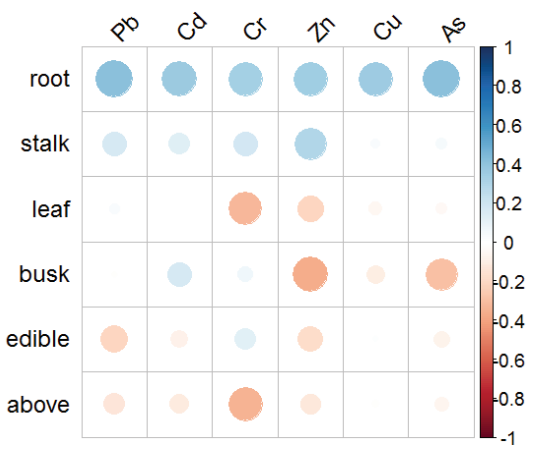

Rice-soil system

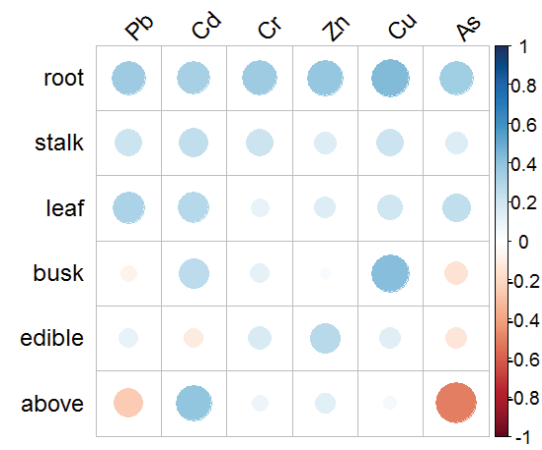

Maize-soil syatem

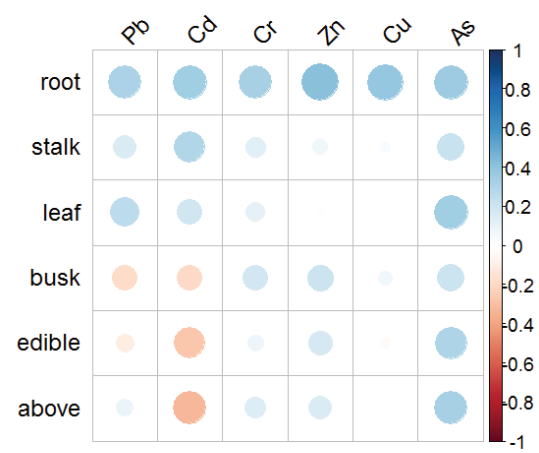

Coix lacryma-jobi L.

Fig. 8: r-values distribution between TEs contents in soil and different tissues of plants. 
in other parts of the plants, which indicates that the sources of the elements in the soil were not the same.

\section{Health Risk Assessment of TEs through the Food Chain}

Target hazard quotient through the food chain quantification health risk, and the assessment process main determined by exposure to various virulence factor (Bhatti et al. 2017). The THQ is a tool to assess the level of risk associated with a particular pollutant. The estimation of the hazard quotient of metals in different crops from various sites is given in Table 6 .

In the entire study area, the THQs for TEs through food (crops) consumption were found to be in the order: $\mathrm{As}>\mathrm{Cd}$ $>\mathrm{Cu}>\mathrm{Pb}>\mathrm{Zn}>\mathrm{Cr}$ (except Coix lacryma-jobi $\mathrm{L}$.). The THQ values in this study were $<1$ for all TEs expect As. The $\mathrm{THQ}_{\mathrm{As}}$ in rice, maize and Coix lacryma-jobi $\mathrm{L}$. was $0 \sim 6.33,0 \sim 1.22$ and $0.56 \sim 3.03$, respectively, which indicates that some samples' THQ was $>1$ and above the safe limits. The mean value of $\mathrm{THQ}_{\mathrm{As}}$ for maize was $<1$ (Table 6), while those of rice and Coix lacryma-jobi $\mathrm{L}$. were $>1$. The results display similar trends with the BAF and TF (rice $>$ Coix lacryma-jobi $\mathrm{L}$. > maize). It is critical to reduce BAF and TF to ensure food safety.

The ranking orders of TTHQ for each plant were rice $>$ Coix lacryma-jobi L. > maize. The potential risk of consumption of rice in the target area is higher than the others. The TTHQ of crop species was $\geq 1$, indicating potential non-carcinogenic risks from ingestion of local crops (rice, maize and Coix lacryma-jobi L.). Since the THQ was $<1$ for TEs in maize, the health risk could be negligible to the inhabitants of the studied area by individual TE, but the combined effect of the metals may pose a health risk. The estimated TTHQ was mainly due to As. The THQ accounted for $76.77 \%$ (rice), $62.86 \%$ (maize) and $66.14 \%$ (Coix lacryma-jobi L.) of the TTHQ.

\section{CONCLUSIONS}

TE content in the investigated agricultural soils were in the order $\mathrm{As}>\mathrm{Pb}>\mathrm{Cu}>\mathrm{Cr}>\mathrm{Cd}>\mathrm{Zn}$. The average TE values were greater than the respective background values of the local area, while the soil contamination content exceeded the national standard.

The results of $\mathrm{I}_{g e o}$ signify that As was at the highest contamination level compared to other TEs, while $\mathrm{Pb}$ and $\mathrm{Cu}$ were at the moderately polluted level, $\mathrm{Cr}$ was in the lightly polluted level, and $\mathrm{Cd}$ and $\mathrm{Zn}$ were not pollutants. The results of RI showed that exceeding $90 \%$ soil sample point is in the considerable potential ecological risk level, especially soil growing Coix lacryma-jobi L., and the highest contributing element was As. Therefore, urgent measures must be taken to control contamination with As in this area.

The $\mathrm{TF}_{\mathrm{Cd}}$ value was significantly higher than other elements, while $\mathrm{Pb}$ was second highest. There was competition in transport and absorption between $\mathrm{Pb}$ and $\mathrm{Cd}$. Comparing the three plants, As was easily absorbed by the rice, while $\mathrm{Cd}$ was easily absorbed by maize and $\mathrm{Cu}$ was easily absorbed by Coix lacryma-jobi L. $\mathrm{Pb}, \mathrm{Cd}, \mathrm{Cr}$ and $\mathrm{As}$ are accumulated in rice, indicating that rice (compared maize and Coix lacry$m a$-jobi L.) has a strong capability to transfer these metals from root to grain. Maize shows lower intake of TEs compared to rice and Coix lacryma-jobi L., while rice enriched the toxic elements.

The TTHQs values for the target area were $\geq 1$, which indicates potential health risks. Therefore, measures must be taken to cut down the contents of TEs in the grain and soil and to use new technology to remove or reduce pollution due to anthropogenic activities.

\section{ACKNOWLEDGEMENT}

This work was supported by National Natural Science

Table 6: THQ and TTHQ values for TEs caused by the consumption of crops.

\begin{tabular}{|c|c|c|c|c|c|c|c|c|}
\hline \multirow{2}{*}{ Stem } & \multirow{2}{*}{ Statistics } & \multicolumn{6}{|c|}{ THQ } & \multirow{2}{*}{ TTHQ } \\
\hline & & $\mathrm{Pb}$ & $\mathrm{Cd}$ & $\mathrm{Cr}$ & $\mathrm{Zn}$ & $\mathrm{Cu}$ & As & \\
\hline \multirow{3}{*}{ Rice } & Minimum & 0.03 & 0.02 & $1.03 \times 10^{-3}$ & 0.07 & 0.11 & 0.00 & 0.23 \\
\hline & Maximum & 0.27 & 0.92 & $3.39 \times 10^{-3}$ & 0.15 & 0.20 & 6.33 & 7.88 \\
\hline & Mean & 0.15 & 0.30 & $1.78 \times 10^{-3}$ & 0.09 & 0.16 & 2.30 & 3.00 \\
\hline \multirow{3}{*}{ Maize } & Minimum & 0.03 & 0.00 & $4.10 \times 10^{-4}$ & 0.04 & 0.08 & 0.00 & 0.14 \\
\hline & Maximum & 0.16 & 0.33 & $5.33 \times 10^{-4}$ & 0.07 & 0.25 & 1.22 & 2.02 \\
\hline & Mean & 0.07 & 0.21 & $4.69 \times 10^{-4}$ & 0.06 & 0.16 & 0.84 & 1.33 \\
\hline \multirow{3}{*}{ Coix lacryma-jobi L. } & Minimum & 0.06 & 0.02 & $1.04 \times 10^{-3}$ & 0.09 & 0.24 & 0.56 & 0.97 \\
\hline & Maximum & 0.32 & 0.45 & $1.39 \times 10^{-3}$ & 0.17 & 0.50 & 3.03 & 4.47 \\
\hline & Mean & 0.13 & 0.28 & $1.11 \times 10^{-3}$ & 0.12 & 0.38 & 1.79 & 2.70 \\
\hline
\end{tabular}


Foundation (21467005). The authors greatly appreciate the language assistance from Mr. Gerry Brauer.

\section{REFERENCES}

Balabanova, B., Stafilov, T., Ba eva, K. and Šajn. 2010. R Biomonitoring of atmospheric pollution with heavy metals in the copper mine vicinity located near Radoviš, Republic of Macedonia. J. Environ. Sci. Health, Part A, 45: 1504-1518.

Bhatti, S.S., Sambyal, V., Singh, J. and Nagpal, A.K. 2017. Analysis of soil characteristics of different land uses and metal bioaccumulation in wheat grown around rivers: Possible human health risk assessment. Environ. Dev. Sustain., 19: 571-588.

Bhutiani, R., Kulkarni, D.B., Khanna, D.R. and Gautam, A. 2017. Geochemical distribution and environmental risk assessment of heavy metals in groundwater of an industrial area and its surroundings, Haridwar, India. Energy. Ecol. Environ., 2: 155-167.

Bi, X.Y., Feng, X.B., Yang, Y.G., Qiu, G.L., Li, G.H., Li, F.L., Liu, T.Z., Fu, Z.Y. and Jin, Z.S. 2006. Environmental contamination of heavy metals from zinc smelting areas in Hezhang County, western Guizhou, China. Environ. Int., 32: 883-890.

Bose, S. and Bhattacharyya, A.K. 2008. Heavy metal accumulation in wheat plant grown in soil amended with industrial sludge. Chemosphere, 70: 1264-1272.

Chen, H.Y., Yuan, X.Y., Li, T.Y., Hu, S., Ji, J.F. and Wang, C. 2016. Characteristics of heavy metal transfer and their influencing factors in different soil-crop systems of the industrialization region, China. Ecotox. Environ. Safe, 126: 193-201.

Chen, P., Huang, W.H. and Tang, X.Y. 2002. Features of arsenic content, occurrence in coal and its effect on environment in China. Coal. Geol. Explor., 30: 1-4.

Cui, L.W., Feng, X.B., Lin, C.J., Wang, X.M., Meng, B., Wang, X. and Wang, H. 2014. Accumulation and translocation of ${ }^{198} \mathrm{Hg}$ in four crop species. Environ. Toxicol. Chem, 33: 334-340.

Ding, Z.H., Zheng, B.S., Zhang, J., Belkin, H.E., Finkelman, R.B., Zhao, F.H., Zhou, D.X., Zhou, Y.S. and Chen, C.G. 1999. Preliminary study on the mode of occurrence of arsenic in high arsenic coals from southwest Guizhou Province. Sci. China. Ser. D, 42: 655-661.

Du, Y., Hu, X.F., Wu, X.H., Shu, Y., Jiang, Y. and Yan, X.J. 2013. Effects of mining activities on Cd pollution to the paddy soils and rice grain in Hunan province, Central South China. Environ. Monit. Assess., 185: 9843-9856.

Dudka, S. and Miller, W.P. 1999. Accumulation of potentially toxic elements in plants and their transfer to human food chain. J. Environ. Sci. Health, Part B, 34: 681-708.

Fang, T., Liu, G.J., Zhou, C.C. and Lu, L.L. 2015. Lead in soil and agricultural products in the Huainan Coal Mining Area, Anhui, China: levels, distribution, and health implications. Environ. Monit. Asse., 187(3): 152.

Fazeli, M.S., Khosravan, F., Hossini, M., Sathyanarayan, S. and Satish, P.N. 1998. Enrichment of heavy metals in paddy crops irrigated by paper mill effluents near Nanjangud, Mysore District, Karnataka, India. Environ. Geol., 34: 297-302.

Förstner, U., Ahlf, W. and Calmano, W. 1993. Sediment quality objectives and criteria development in Germany. Water. Sci. Technol., 28: 307-316.

Funtua, M., Agbaji, E. and Pam, A. 2014. Heavy metals contents in soils and some crops irrigated along the Bindare Stream Zaria-Kaduna State, Nigeria. American. Chemical. Science. Journal, 4: 855-864.

Garty, J. 2001. Biomonitoring atmospheric heavy metals with lichens: theory and application. Crit. Rev. Plant. Sci., 20: 309-371.

Häkanson, L. 1980. An ecological risk index for aquatic pollution control: A sediment to logical approach. Water. Res., 14: 975-1001.

Hu, W.Y., Chen, Y., Huang, B. and Niedermann, S. 2014. Health risk assessment of heavy metals in soils and vegetables from a typical greenhouse vegetable production system in China. Hun. Ecol. Risk. Asse., 20: 1264-1280.

Khan, A., Kha, S., Khan, M.A., Qamar, Z. and Waqas, M. 2015. The uptake and bioaccumulation of heavy metals by food plants, their effects on plants nutrients, and associated health risk: A review. Environ. Sci. Pollut., 22: 13772-13799.

Khan, S., Rehman, S., Khan, A.Z., Khan, M.A. and Shah, M.T. 2010. Soil and vegetables enrichment with heavy metals from geological sources in Gilgit, northern Pakistan. Ecotox. Environ. Safe., 73: 1820-1827.

Li, Y.M., Ma J.H., Liu D.X., Sun Y.L. and Chen Y.F. 2015. Assessment of heavy metal pollution and potential ecological risks of urban soils in Kaifeng city, China. Environ. Sci, 36: 1034-1044.

Li, Z.Y., Ma, Z.W., Van der Kuijp, T.J., Yuan, Z.W. and Huang, L. 2014. A review of soil heavy metal pollution from mines in China: pollution and health risk assessment. Sci. Total. Environ, 468: 843-853.

Liao, J.B., Wen, Z.W., Ru, X., Chen, J.D., Wu, H.Z. and Wei, C.H. 2016. Distribution and migration of heavy metals in soil and crops affected by acid mine drainage: Public health implications in Guangdong Province, China. Ecotox. Environ. Safe., 124: 460-469.

Liu, C.P., Luo, C.L., Gao, Y., Li, F.B., Lin, L.W., Wu, C.A. and Li, X.D. 2010. Arsenic contamination and potential health risk implications at an abandoned tungsten mine, southern China. Environ. Pollut., 158: 820-826.

Liu, H.Y., Probst, A. and Liao, B.H. 2005. Metal contamination of soils and crops affected by the Chenzhou lead/zinc mine spill (Hunan, China). Sci. Total. Environ., 339: 153-166.

Loutfy, N., Fuerhacker, M., Tundo, P., Raccanelli, S., EL Dien, A. and Ahmed, M.T. 2006. Dietary intake of dioxins and dioxin-like PCBs, due to the consumption of dairy products, fish/seafood and meat from Ismailia city, Egypt. Sci. Total. Environ., 370: 1-8.

MEPPRC 1990. Background Concentrations of Elements in Soils of China. Ministry of Environmental Protection of the People's Republic of China, China Environmental Science Press, Beijing.

MHPRC 2012. Maximum Levels of Contaminants in Food (GB 27622012). Ministry of Health of the People's Republic of China, Chinese Standard Press, Beijing.

Mico, C., Recatala, L., Peris, M. and Sánchez, J. 2006. Assessing heavy metal sources in agricultural soils of a Europea Mediterranean area by multivariate analysis. Chemosphere, 65: 863-872.

Müller, G. 1969. Index of geo-accumulation in sediments of the Rhine river. Geo. Journal, 2: 108-118.

Najafi, S. and Jalali, M. 2015. Effects of organic acids on cadmium and copper sorption and desorption by two calcareous soils. Environ. Monit. Assess., 187: 585.

Nan, Z.G., Li, J.J., Zhang, J.M. and Cheng, G.D. 2002. Cadmium and zinc interactions and their transfer in soil-crop system under actual field conditions. Sci. Total. Environ., 285: 187-195.

Pruvot, C., Douay, F., Hervé, F. and Waterlot, C. 2006. Heavy metals in soil, crops and grass as a source of human exposure in the former mining areas. J. Soil. Sediment, 6: 215-220.

Qin, F.X., Wei, C.F., Zhong, S.Q., Huang, X.F., Pang, W.P. and Jiang, X. 2016. Soil heavy metal (loid)s and risk assessment in vicinity of a coal mining area from southwest Guizhou, China. J. Cent. South. Univ., 23: 2205-2213.

Qishlaqi, A., Moore, F. and Forghani, G. 2008. Impact of untreated wastewater irrigation on soils and crops in Shiraz suburban area, SW Iran. Environ. Monit. Assess., 141: 257-273.

Qu, Q.Y., Liu, G.J., Sun, R.Y. and Kang, Y. 2016. Geochemistry of tin (Sn) in Chinese coals. Environ. Geochem. Hlth., 38: 1-23.

Rahman, M.A., Rahman, M.M., Reichman, S.M., Lim, R.P. and Naidu, R. 2014. Heavy metals in Australian grown and imported rice and vegetables on sale in Australia: Health hazard. Ecotox. Environ. Safe., 100(1): 53-60. 
Rattan, R.K., Datta, S.P., Chhonkar, P.K., Suribabu, K. and Singh, A.K. 2005. Long-term impact of irrigation with sewage effluents on heavy metal content in soils, crops and groundwater-a case study. Agr. Ecosyst. Enviro., 109(3): 310-322.

Razo, I., Carrizales, L., Castro, J., Díaz-Barriga, F. and Monroy, M. 2004. Arsenic and heavy metal pollution of soil, water and sediments in a semi-arid climate mining area in Mexico. Water. Air. Soil. Poll., 152: 129-152.

Shamshuddin, J., Elisa Azura, A., Shazana, M.A.R.S., Fauziah, C.I., Panhwar, Q.A. and Naher, U.A. 2014. Properties and management of acid sulfate soils in Southeast Asia for sustainable cultivation of rice, oil palm and cocoa. Adv. Agron., 124: 91-142.

Shen, W.T., Wu, Y.G., Huang, B.P., Wang, L.T., Liao, F. and Chen, C. 2011. Heavy metal contamination and enzyme activity of topsoil in abandoned coal mining area in Xingren County of Guizhou Province. Guizhou. Agr. Sci., 39: 111-115.

Shi, P., Xiao J., Wang, Y. and Chen, L. 2014. Assessment of ecological and human health risks of heavy metal contamination in agriculture soils disturbed by pipeline construction. Int. J. Environ. Res. Public Health, 11: $2504-2520$.

Singani, A.A.S. and Ahmadi, P. 2012. Manure application and cannabis cultivation influence on speciation of lead and cadmium by selective sequential extraction. Soil. Sediment. Contam., 21: 305-321.

Singh, R., Singh, D.P., Kumar, N., Bhargava, S.K. and Barman, S.C. 2010. Accumulation and translocation of heavy metals in soil and plants from fly ash contaminated area. J. Environ. Biol., 31: 421-430.

Sun, J., Tang, C.Y., Wu, P., Liu, C.Q. and Zhang, R.X. 2013. Migration of $\mathrm{Cu}, \mathrm{Zn}, \mathrm{Cd}$ and $\mathrm{As}$ in epikarst water affected by acid mine drainage at a coalfield basin, Xingren, Southwest China. Environ. Earth. Sci., 69: 2623-2632.

Sun, Y.B., Zhou, Q.X., Xie, X.K and Liu, R. 2010. Spatial, sources and risk assessment of heavy metal contamination of urban soils in typical regions of Shenyang, China. J. Hazard. Mater., 174, 455-462.

Tang, C.Y., Wu, P., Tao, X.Z., Zhang, C.P. and Han, Z.W. 2009. The basin acidification affected by AMD: A case study in Xingren county, Guizhou, China. Carsologica Sinica, 28: 135-143.

US EPA.1997. Integrated Risk Information System Database. United States Environmental Protection Agency, Washington, DC. http://www2.epa. gov/iris/iris-recent-additions-2013-1997.

Wang, S.Y., Wu, W.Y., Liu, F., Liao, R.K. and Hu, Y.Q. 2017. Accumulation of heavy metals in soil-crop systems: a review for wheat and corn. Environ. Sci. Pollut. R, 24: 15209-15225.

Wang, X.Q., Zeng, X.D., Liu, C.Q., Li, F.B., Xu, X.H. and Lv, Y.H. 2016. Heavy metal contaminations in soil-rice system: source identification in relation to a sulfur-rich coal burning power plant in Northern Guangdong Province, China. Environ. Monit. Assess., 188: 1-12.

Wu, P., Tang CY., Liu CQ., Zhu LJ., Pei TQ. and Feng LJ. 2009. Geochemical distribution and removal of $\mathrm{As}, \mathrm{Fe}, \mathrm{Mn}$ and $\mathrm{Al}$ in a surface water system affected by acid mine drainage at a coalfield in Southwestern China. Environ. Geol., 57: 1457-1467.

Yang, J.Y. 2006. Concentrations and modes of occurrence of trace elements in the Late Permian coals from the Puan Coalfield, southwestern Guizhou, China. Environ. Geochem. Hlth., 28: 567-576.

Yang, W.H. and Liu, Y.M. 1997. Sediment-hosted gold deposits in China-geochemistry and prospecting. Chin. J. Geochem., 16: 202-212.

Yang, Z.J., Tang, Y.G., Zheng, X., Li, J.J., Han, W.L. and Yang, S.T. 2006. Enrichment of arsenic, antimony, thallium and selenium in high-arsenic coal from Xingren County, Guizhou Province. Chin. J. Geochem., 25: 50 .

Yisa, N.J., John, J.O. and Onoyima, C.C. 2012. Assessment of toxic levels of some heavy metals in road deposited sediments in Suleja, Nigeria. Am. J. Chem., 2: 34-37.

Yu, R.L., Yuan, X., Zhao, Y.H., Hu, G.R. and Tu, X.L. 2008. Heavy metal pollution in intertidal sediments from Quanzhou Bay. J. Environ. Sci. China, 20: 664-669.

Zarcinas, B.A., Pongsakul, P., McLaughlin, M.J. and Cozens, G. 2004. Heavy metals in soils and crops in Southeast Asia 2. Thailand. Environ. Geochem. Hlth., 26: 359-371.

Zeng, F.F., Wei, W., Li, M.S., Huang, R.X., Yang, F. and Duan, Y.Y. 2015. Heavy metal contamination in rice-producing soils of Hunan province, China and potential health risks. Int. J. Environ. Res. Public. Health, 12: $15584-15593$.

Zeng, H.A. and Wu, J.L. 2013. Heavy metal pollution of lakes along the mid-lower reaches of the Yangtze river in China: intensity, sources and spatial patterns. Int. J. Environ. Res. Public Health, 10: 793-807.

Zeng, X.F., Wang, Z.W., Wang, J., Guo, J.T., Chen, X.J. and Zhuang, J. 2015. Health risk assessment of heavy metals via dietary intake of wheat grown in Tianjin sewage irrigation area. Ecotoxicology, 24: 2115-2124.

Zhang, Y., Hu, X.N. and Tao, Y. 2012. Distribution and risk assessment of metals in sediments from Taihu Lake, China using multivariate statistics and multiple tools. B. Environ. Contam. Tox., 89: 1009-1015.

Zhao, F.H., Ren, D.Y., Zheng, B.S., Hu, T.D. and Liu, T. 1998. Modes of occurrence of arsenic in high-arsenic coal by extended X-ray absorption fine structure spectroscopy. Chinese Sci. Bull., 43: 1660-1663.

Zhuang, W. and Gao, X.L. 2014. Integrated assessment of heavy metal pollution in the surface sediments of the Laizhou Bay and the coastal waters of the Zhangzi Island, China: Comparison among typical marine sediment quality indices. Plos. One, 9: e94145. 